\title{
Kekerabatan rayap tanah Macrotermes gilvus Hagen (Blattodea: Termitidae) dari dua habitat di Bogor
}

\author{
Relatedness of the subterranean termites Macrotermes gilvus Hagen \\ (Blattodea: Termitidae) from two habitats in Bogor \\ Nadzirum Mubin ${ }^{1}$, Idham Sakti Hararap ${ }^{1}$, Giyanto $^{1}$, Rika Raffiudin ${ }^{2}$ \\ ${ }^{1}$ Departemen Proteksi Tanaman, Fakultas Pertanian, Institut Pertanian Bogor \\ Jalan Kamper, Kampus IPB Dramaga, Bogor 16680 \\ ${ }^{2}$ Departemen Biologi, Fakultas Matematika Ilmu Pengetahuan Alam, Institut Pertanian Bogor \\ Jalan Agatis, Kampus IPB Dramaga, Bogor 16680
}

(diterima September 2014, disetujui Mei 2015)

\begin{abstract}
ABSTRAK
Rayap tanah Macrotermes gilvus (Hagen) (Blattodea: Termitidae) yang termasuk ke dalam subfamili Macrotermitinae tersebar luas di Asia Tenggara, diantaranya Indonesia, Malaysia, Singapura, Myanmar, Filipina, Vietnam, dan Thailand. Kajian tentang rayap ini sudah banyak dilakukan, akan tetapi kajian tentang hubungan kekerabatan rayap pada habitat yang berbeda belum banyak dilakukan. Penelitian ini bertujuan untuk menganalisis kekerabatan rayap tanah M. gilvus di Kampus Institut Pertanian Bogor, Dramaga dan Cagar Alam Yanlappa, Jasinga-Bogor. Analisis kekerabatan rayap menggunakan pendekatan perilaku agonistik dan teknik molekuler menggunakan DNA mitokondria gen COI. Hasil penelitian ini menunjukkan bahwa berdasarkan pendekatan perilaku rayap-rayap yang berasal dari kedua lokasi berasal dari tetua yang berbeda. Walaupun demikian, berdasarkan teknik molekuler rayap-rayap dari kedua lokasi mempunyai kekerabatan yang sangat dekat. Pendekatan perilaku yang diujikan menunjukkan bahwa diantara koloni rayap yang diujikan berasal dari tetua yang berbeda. Sedangkan, pengujian dengan deteksi molekuler masih belum bisa menunjukkan hasil yang selaras dengan uji agonistik.
\end{abstract}

Kata kunci: agonistik, gen COI, Macrotermitinae, mitokondria, Termitidae

\begin{abstract}
Subterranean termites Macrotermes gilvus (Hagen) (Blattodea: Termitidae) belongs to the subfamily Macrotermitinae they are distributed widely in Southeast Asia such as Indonesia, Malaysia, Singapore, Myanmar, Philippine, Vietnam, and Thailand. Many studies on these termites have been conducted, but the study of relatedness termites from different locations are barely done. The objective of this study was analyze the relatedness between subterranean termites M. gilvus in IPB Dramaga Campus and Yanlappa Nature Reserve, Jasinga-Bogor. The termite relatedness was analyzed with agonistic behavioral approach and molecularly, technique using mitochondrial COI gene. Termites from both locations showed identical molecular relatedness, however behavioral analysis show that they belong from different parental lineages. Agonistic assessment showed that individuals from different habitat showed aggressive behaviour, whereas those that originated from the same nest do not show any aggression. Molecular detection however have failed to show.
\end{abstract}

Key word: agonistic, COI gene, Macrotermitinae, mitochondria, Termitidae

\footnotetext{
*Penulis korespondensi: Nadzirun Mubin. Departemen Proteksi Tanaman, Fakultas Pertanian, Institut Pertanian Bogor, 


\section{PENDAHULUAN}

Rayap (Blattodea: Termitoidae) merupakan serangga sosial yang mempunyai persebaran sangat luas. Keanekaragaman rayap diperkirakan lebih dari 2600 spesies yang tersebar di seluruh dunia (Pearce 1997; Ohkuma et al. 2004). Termitidae merupakan famili rayap yang mempunyai anggota koloni paling banyak dibandingkan dengan famili rayap yang lain. Salah satu subfamili dari Termitidae, yaitu subfamili Macrotermitinae yang terdiri atas lima genus, yaitu Macrotermes, Odontotermes, Microcerotermes, Hypotermes, dan Microtermes (Noirot 1969; Tho 1992). Macrotermes merupakan genus rayap dari subfamili Macrotermitinae yang banyak dijadikan bahan kajian penelitian. Kajian tentang rayap Macrotermes, seperti pada spesies rayap Macrotermes barneyi Light (Wei et al. 2012), Macrotermes subhyalinus Rambur (Cameron et al. 2012), dan Macrotermes gilvus (Hagen) (Pribadi et al. 2011; Mubin 2013; Ferbiyanto et al. 2015).

M. gilvus tersebar luas di seluruh daratan Indonesia (Tarumingkeng 1971). Kajian penelitian yang sudah dilakukan, seperti pengamatan morfologi rayap (Roonwal \& Chhotani 1961), morfologi dan struktur sarang (Subekti et al. 2007; Subekti 2010), dan keanekaragaman (Primanda et al. 2003; Pribadi et al. 2011; Mubin 2013). Namun kajian tentang hubungan kekerabatan rayap M. gilvus pada habitat yang berbeda belum ada.

Kekerabatan rayap dapat dilakukan dengan menggunakan beberapa pendekatan, seperti pendekatan perilaku dan teknik molekuler. Pendekatan perilaku digunakan untuk melihat agresifitas rayap, yaitu dengan melihat perilaku agonistik atau perilaku yang terlihat pada rayap saat proses pengenalan isyarat (Shelton \& Grace 1996). Pendekatan menggunakan teknik molekuler merupakan pendukung dari identifikasi berdasarkan morfologi (Busse et al. 1996). Identifikasi morfologi yang didukung dengan pendekatan molekuler akan diperoleh data yang lebih akurat (Jinbo et al. 2011).

Kajian yang telah dilakukan Legendre et al (2008), yaitu melihat kekerabatan menggunakan gen pada inti maupun mitokondria rayap sebanyak 40 sampel yang mewakili setiap famili. Hasil yang diperoleh menunjukkan bahwa semua sampel rayap yang digunakan membentuk cabang monofiletik dengan rayap Mastotermes darwiniensis Froggatt (famili Mastotermitidae) sebagai sister group dari rayap yang paling primitif. Famili Kalotermitidae menjadi sister group dengan famili rayap yang lain (Legendre et al. 2008).

Rayap merupakan salah satu serangga yang hidup di alam dan membutuhkan selulosa dari kayu untuk memenuhi kebutuhan makannya. Habitat yang banyak terdapat kayu atau bahan selulosa yang lainnya merupakan tempat tinggal yang baik bagi rayap. Kajian tentang serangga ini pada habitat yang berbeda sudah banyak dilakukan, akan tetapi kajian tentang kekerabatannya masih belum dilakukan. Penelitian ini bertujuan untuk mengetahui kekerabatan rayap dari habitat yang berbeda, yaitu Kampus Institut Pertanian Bogor (IPB) Dramaga dan Cagar Alam (CA) Yanlappa Jasinga-Bogor menggunakan pendekatan perilaku agonistik dan teknik molekuler menggunakan DNA gen Cytochrome Oxydase I (COI).

\section{BAHAN DAN METODE}

\section{Pengambilan sampel rayap}

Spesies rayap yang dikoleksi adalah $M$. gilvus. Rayap diperoleh dari hasil koleksi dari dua habitat yang berbeda, yaitu Kampus IPB Dramaga dan CA Yanlappa Jasinga, Bogor kerena pada lokasi tersebut kelimpahan rayap M. gilvus tinggi (Subekti 2010; Mubin 2013). Kampus IPB Dramaga merupakan kawasan dengan kondisi lingkungan yang sebagian besar berupa permukiman, sedangkan CA Yanlappa merupakan kawasan hutan dengan kondisi habitat yang masih alami. Rayap dikoleksi dengan teknik transek strip sensus dengan ukuran $1 \mathrm{~m}$ x $10 \mathrm{~m}$. Peneliti berjalan sepanjang garis transek, jika ditemukan rayap maka dikoleksi dan dicatat posisinya menggunakan global positioning system (GPS) Garmin 64s.

Tiga koloni rayap diambil dari masingmasing lokasi. Rayap yang sudah dikoleksi akan digunakan untuk uji kekerabatan berdasarkan pendekatan perilaku agonistik dan deteksi molekuler menggunakan DNA gen COI.

\section{Analisis kekerabatan rayap tanah M. gilvus dengan pendekatan perilaku}

Uji agonistik rayap. Rayap pekerja hasil koleksi digunakan untuk pengujian agonistik. 
Satu individu rayap pekerja dari dua koloni yang berbeda (jarak antar individu $5 \mathrm{~cm}$ ) ditempatkan di wadah plastik sebagai arena pengujian dan diamati perilakunya (Delphia et al. 2003). Setiap koloni rayap yang diperoleh dari lapangan diujikan dengan keseluruhan koloni rayap yang ditemukan. Hasil perilaku agonistik pada tiap koloni rayap dicatat dan dianalisis.

Analisis kekerabatan rayap tanah $M$. gilvus dengan teknik molekuler

Ekstraksi DNA rayap. Rayap kasta pekerja diekstraksi menggunakan metode cetyl trimetil ammonium bromide (CTAB) dari metode Sambrook et al. (1989) yang telah dimodifikasi (Mubin 2014). Pelet DNA rayap hasil ekstraksi disuspensikan kembali dengan $30 \mu \mathrm{L} \quad 0,5 \mathrm{mM}$ bufer TE $\mathrm{pH} 8$.

Amplifikasi gen COI pada rayap. Amplifikasi gen COI pada rayap dilakukan untuk dua individu $M$. gilvus dari tiap lokasi pengambilan sampel. Amplifikasi fragmen gen COI M. gilvus menggunakan primer forward (F5'GATTACTACCACCAT CACTAACC-3') dan reverse (R5'-ACTACTCCTGTAAGTCCTCCTA T-3') dengan panjang amplikon sebesar 762 pasang basa (pb) (Mubin 2014).

Total volume pereaksi PCR yang digunakan adalah $25 \mu$ l. Pereaksi tersebut terdiri atas $9,5 \mu 1$ air destilata, $1 \mu \mathrm{l}$ masing-masing primer $20 \mathrm{pmol}$, $1 \mu \mathrm{l}$ DNA cetakan, dan 12,5 $\mu 12 \mathrm{x}$ Ready Mix (Dream taq Green Fermentas). Program PCR yang digunakan berdasarkan Singla et al. (2013) dengan modifikasi suhu annealing dan jumlah siklus PCR-nya. Kondisi PCR terdiri atas predenaturation pada suhu $94{ }^{\circ} \mathrm{C}$ (5 menit), siklus yang digunakan sebanyak 35 (denaturation $94{ }^{\circ} \mathrm{C}$, 1 menit; annealing $50{ }^{\circ} \mathrm{C}, 30$ detik; extension $72^{\circ} \mathrm{C}, 1$ menit), danfinal elongation $72{ }^{\circ} \mathrm{C}(7$ menit). DNA rayap hasil amplifikasi dielektroforesis menggunakan agarose $1 \%$ pada 75 volt selama 30 menit dan divisualisasi menggunakan UV transluminator.

Sekuensing DNAgen COI. Produk amplifikasi gen COI disekuensing (perusahaan First Base Asia), selanjutnya diolah menggunakan piranti lunak BioEdit 7.2 untuk dibandingkan dengan pangkalan data sekuen dari GenBank (www.ncbi. nlm.nih.gov).

Analisis homologi, filogenetika, dan jarak genetik DNA rayap. Sekuen yang telah diperoleh dari perusahaan sekuensing kemudian dilakukan basic local alignment search tool-nucleotide (BLAST-N) untuk mengetahui homologi sekuen nukleotida target ( $M$. gilvus) dengan sekuen di Database Genbank. Hasil sekuen yang telah diBLAST-N kemudian digunakan untuk tahap berikutnya, yaitu sekuen nukleotida gen COI $M$. gilvus di-alignment dengan data sekuen nukleotida gen COI rayap anggota Termitidae yang diperoleh dari GenBank (Tabel 1). Konstruksi pohon filogenetika dilakukan antar gen COI M. gilvus (in-group) dan spesies rayap M. annandalei (outgroup) (Tabel 1). Proses analisis filogenetika tersebut menggunakan metode neighbor-joining

Tabel 1. Database gen COI in-group dan out-group yang diperoleh dari GenBank untuk analisis filogenetika dan jarak genetik

\begin{tabular}{|c|c|c|c|c|}
\hline Group & Organisme & Famili & Kode & No. aksesi \\
\hline \multirow[t]{9}{*}{ In-group } & Macrotermes gilvus & Termitidae & $\mathrm{Mg} 4 \mathrm{DMG}$ & - \\
\hline & M. gilvus & Termitidae & $\mathrm{Mg} 6 \mathrm{DMG}$ & - \\
\hline & M. gilvus & Termitidae & $\mathrm{Mg} 4 \mathrm{JSG}$ & - \\
\hline & M. gilvus & Termitidae & $\mathrm{Mg} 5 \mathrm{JSG}$ & - \\
\hline & M. gilvus & Termitidae & Mg 13 LAO & AB909013 \\
\hline & M. gilvus & Termitidae & Mg 14 LAO & AB909014 \\
\hline & M. gilvus & Termitidae & Mg 15 LAO & AB909015 \\
\hline & M. gilvus & Termitidae & $\mathrm{Mg} 16 \mathrm{LAO}$ & AB909016 \\
\hline & M. gilvus & Termitidae & $\mathrm{Mg} 17 \mathrm{LAO}$ & AB909017 \\
\hline \multirow[t]{2}{*}{ Out-group } & M. annandalei & Termitidae & Man 09 LAO & AB909009 \\
\hline & M. annandalei & Termitidae & Man $10 \mathrm{LAO}$ & AB909010 \\
\hline
\end{tabular}

Mg: Macrotermes gilvus; DMG/D: Kampus IPB Dramaga; JSG/J: CA Yanlappa-Jasinga; LAO: spesiemen rayap asal Laos. 
(NJ) dan maximum parsimony (MP) dengan bootstrap 1000x pada program MEGA 5 (Tamura et al. 2011). Analisis jarak genetik dilakukan antara gen COI M. gilvus dan M. annandalei (Tabel 1) menggunakan program BioEdit Versi 7.2.

\section{HASIL}

Koloni rayap tanah M. gilvus dari habitat yang berbeda

Spesies rayap $M$. gilvus melimpah di CA Yanlappa dan di Kampus IPB Dramaga. Koloni rayap yang ditemukan di lapangan sebanyak 3 kolonipada setiap lokasi, yaitu Mg 3 JSG, Mg 4 JSG, dan Mg 6 JSG (koloni rayap dari CA Yanlappa), sedangkan koloni dari Kampus Dramaga, yaitu Mg 2 DMG, Mg 4 DMG, dan Mg 6 DMG.

Analisis kekerabatan rayap tanah M. gilvus dengan pendekatan perilaku

Uji agonistik rayap. Pengujian rayap di dalam arena dengan jarak $\pm 5 \mathrm{~cm}$ memperlihatkan perilaku yang beragam. Dari hasil pengujian agonistik, tampak bahwa rayap dari koloni yang berasal dari lokasi yang sama (CA YanlappaJasinga atau Kampus IPB Dramaga) tidak menunjukkan adanya perilaku agresif, yaitu dengan tidak saling menyerang. Akan tetapi, rayap yang diuji dari lokasi yang berbeda (rayap dari CA Yanlappa-Jasinga dan Kampus IPB Dramaga) terlihat adanya perilaku saling menyerang, yaitu kedua rayap saling menggigit (Tabel 2).
Analisis kekerabatan rayap tanah M. gilvus dengan pendekatan molekuler

Analisis homologi DNA rayap. Primer forward dan reverse mampu mengamplifikasi gen COI dengan baik, terlihat pita DNA 1 sampai 4 merupakan hasil amplifikasi gen COI dari rayap. Pita DNA 1 dan 2 berasal dari DNA total rayap pekerja dari CA Yanlappa-Jasinga, sedangkan pita DNA 3 dan 4 berasal dari DNA total rayap pekerja Kampus IPB. Pita yang terlihat sesuai dengan target yang diinginkan, yaitu berukuran sekitar $750 \mathrm{pb}$ (Gambar 1).

Sekuen DNA rayap dari Kampus IPB Dramaga (2 sekuen) dan CA Yanlappa-Jasinga (2 sekuen) berasal dari proses sekuensing dari hasil amplifikasi gen COI. Hasil alignment keempat sekuen dari DNA rayap Kampus IPB Dramaga dan CA Yanlappa Jasinga ditemukan kemiripan yang sama pada semua basa nukleotida. Hasil BLAST-N dari sekuen DNA rayap Mg 4 DMG (mewakili

Tabel 2. Hasil uji agonistik rayap Macrotermes gilvus dari CA Yanlappa dan Kampus IPB Dramaga

\begin{tabular}{ccccccc}
\hline & J3 & J4 & J6 & D2 & D4 & D6 \\
\hline$[\mathrm{J} 3]$ & & - & - & $\sqrt{ }$ & $\sqrt{ }$ & $\sqrt{ }$ \\
{$[\mathrm{J} 4]$} & - & & - & $\sqrt{ }$ & $\sqrt{ }$ & $\sqrt{ }$ \\
{$[\mathrm{J} 6]$} & - & - & & $\sqrt{ }$ & $\sqrt{ }$ & $\sqrt{ }$ \\
{$[\mathrm{D} 2]$} & $\sqrt{ }$ & $\sqrt{ }$ & $\sqrt{ }$ & & - & - \\
{$[\mathrm{D} 4]$} & $\sqrt{ }$ & $\sqrt{ }$ & $\sqrt{ }$ & - & & - \\
{$[\mathrm{D} 6]$} & $\sqrt{ }$ & $\sqrt{ }$ & $\sqrt{ }$ & - & - & \\
\hline
\end{tabular}

J3: Mg 3 JSG; J4: Mg 4 JSG; J6: Mg 6 JSG; D2: Mg 2 DMG; D4: Mg 4 DMG; dan D6: Mg 6 DMG; $\sqrt{\text { : menunjukkan }}$ perilaku agresif; -: tidak menunjukkan perilaku agresif.

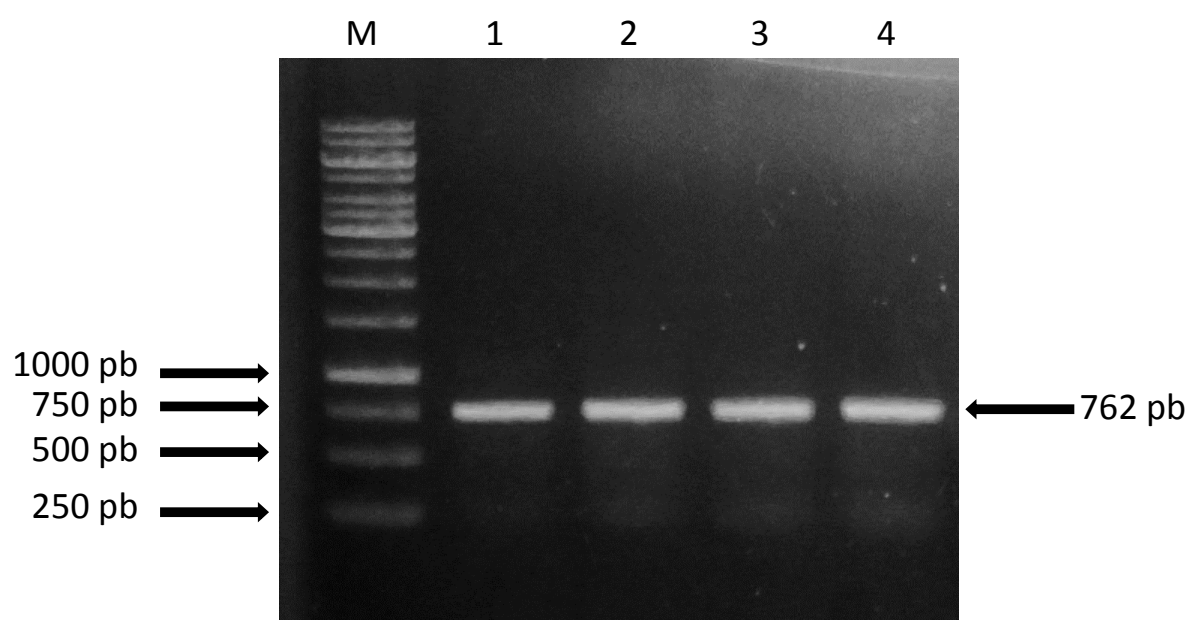

Gambar 1. Visualisasi hasil amplifikasi gen COI rayap dari CA Yanlappa dan Kampus IPB Dramaga menggunakan primer spesifik. Sumuran M, 1, 2, 3, dan 4 berturut-turut adalah Marker $1 \mathrm{~kb}$, sampel Mg 4 JSG, Mg 6 JSG, Mg 4 DMG, dan Mg 6 DMG. 
sekuen rayap dari Kampus IPB maupun CA Yanlappa) mempunyai homologi dengan rayap $M$. gilvus dari Laos (Mg 15 LAO) dengan nilai query cover, e-value, dan max-identity berturut-turut adalah $100 \%, 0,0 \%$, dan $98 \%$ (Tabel 3). Sekuen gen COI rayap dari hasil BLAST-N menunjukkan hasil yang sama dengan spesies rayap yang digunakan dalam pengujian, yaitu merujuk pada spesies rayap $M$. gilvus.

Sekuen-sekuen DNA rayap $M$. gilvus dari Bogor tidak ada perbedaannya setelah dialignment. Akan tetapi, sekuen-sekuen DNA rayap dari Bogor yang dibandingkan dengan sekuen DNA rayap haplotipe dari Laos terdapat beberapa perbedaan sekuen nukleotida. Sebanyak 17 basa nukleotida yang berbeda antara sekuen DNA rayap dari Bogor dibandingkan dengan sekuen DNA rayap dari Laos (Tabel 4).

Analisis filogenetika dan jarak genetik rayap. Analisis filogenetika 732 basa dari gen COI rayap $M$. gilvus diperoleh bahwa sebanyak 715 basa konstan, basa variable sebanyak 17 (2,32\%), dan parsimony-informatif sebanyak 17 (2,32\%). Jumlah basa konstan yang diperoleh tergolong sangat tinggi, sedangkan basa variable dan parsimony-informatif (adanya karakter yang berbeda setelah proses pengurutan sekuen basa nukleotida) mempunyai nilai yang sangat rendah. Hal ini disebabkan karena rayap yang dikaji berada dalam tingkatan intraspesies sehingga mempunyai nilai basa variable dan parsimony-informatif yang rendah.

Konstruksi pohon filogenetika dengan metode NJ dan MP menunjukkan sedikit perbedaan pada percabangan antara rayap-rayap di Bogor. Rayap dari Bogor pada pohon filogenetika NJ tidak membentuk percabangan (Gambar 2), sedangkan pada pohon filogenetika MP membentuk percabangan (Gambar 3), walaupun dengan nilai kepercayaan (bootstrap) yang rendah, yaitu 30\% dan $20 \%$.

Rayap dari Bogor mempunyai nilai kedekatan dengan nilai bootstrap 100 dan didukung dengan nilai jarak genetik sebesar 100\% (Tabel 5). Hal ini menunjukkan bahwa rayap dari Bogor yang terdiri atas rayap koloni CA Yanlappa-Jasinga dan Kampus IPB Dramaga mempunyai kekerabatan yang sangat dekat berdasarkan gen COI.

Tabel 3. Hasil BLAST-N sekuen gen COI dari rayap pekerja Mg 4 DMG

\begin{tabular}{lclccccc}
\hline No. Aksesi & Haplotipe & \multicolumn{1}{c}{ Spesies } & $\begin{array}{c}\text { Skor } \\
\text { maksimum }\end{array}$ & $\begin{array}{c}\text { Skor } \\
\text { total }\end{array}$ & $\begin{array}{c}\text { Query } \\
\text { cover }(\%)\end{array}$ & $\begin{array}{c}\text { e-value } \\
\text { Identity }\end{array}$ \\
\hline AB909015 & H3 & Macrotermes gilvus & 1269 & 1269 & 100 & 0,0 & $98 \%$ \\
AB909017 & H5 & M. gilvus & 1264 & 1264 & 100 & 0,0 & $98 \%$ \\
AB909014 & H2 & M. gilvus & 1264 & 1264 & 100 & 0,0 & $98 \%$ \\
AB909013 & H1 & M. gilvus & 1264 & 1264 & 100 & 0,0 & $98 \%$ \\
AB909016 & H4 & M. gilvus & 1258 & 1258 & 100 & 0,0 & $98 \%$ \\
\hline
\end{tabular}

H: Haplotipe.

Tabel 4. Posisi nukleotida gen COI Macrotermes gilvus dengan database sekuen nukleotida berdasarkan GenBank yang menunjukkan variasi haplotipe

\begin{tabular}{|c|c|c|c|c|c|c|c|}
\hline \multirow[b]{2}{*}{ Sampel } & \multicolumn{7}{|c|}{ Nukleotida ke- } \\
\hline & $\begin{array}{c}12 / 90 / 384 / 399 \\
414 / 639 \\
\end{array}$ & $33 / 264$ & $\begin{array}{c}39 / 174 / 341 \\
/ 534 / 611 \\
\end{array}$ & 200 & 258 & 408 & 706 \\
\hline $\mathrm{Mg} 4 \mathrm{DMG}$ & $\mathrm{C}$ & $\mathrm{G}$ & $\mathrm{T}$ & $\mathrm{G}$ & $\mathrm{T}$ & $\mathrm{A}$ & $\mathrm{T}$ \\
\hline Mg 6 DMG & . & . & . & . & . & . & . \\
\hline Mg 4 JSG & . & . & . & . & . & . & . \\
\hline Mg 5 JSG & . & . & . & . & . & . & . \\
\hline $\mathrm{Mg} 13 \mathrm{LAO}$ & $\mathrm{T}$ & A & $\mathrm{C}$ & $\mathrm{C}$ & $\mathrm{C}$ & $\mathrm{G}$ & . \\
\hline Mg 14 LAO & $\mathrm{T}$ & A & $\mathrm{C}$ & $\mathrm{C}$ & $\mathrm{C}$ & G & . \\
\hline $\mathrm{Mg} 15 \mathrm{LAO}$ & $\mathrm{T}$ & $\mathrm{A}$ & $\mathrm{C}$ & $\mathrm{C}$ & . & $\mathrm{G}$ & . \\
\hline $\mathrm{Mg} 16 \mathrm{LAO}$ & $\mathrm{T}$ & A & $\mathrm{C}$ & $\mathrm{C}$ & $\mathrm{C}$ & G & G \\
\hline Mg 17 LAO & $\mathrm{T}$ & A & $\mathrm{C}$ & $\mathrm{C}$ & • & $\mathrm{G}$ & $\mathrm{G}$ \\
\hline
\end{tabular}

Mg: M. gilvus; JSG: CA Yanlappa-Jasinga; DMG: Kampus IPB-Dramaga; LAO: Laos (asal spesimen rayap); (.): menunjukkan basa yang sama dengan basa yang paling atas. 


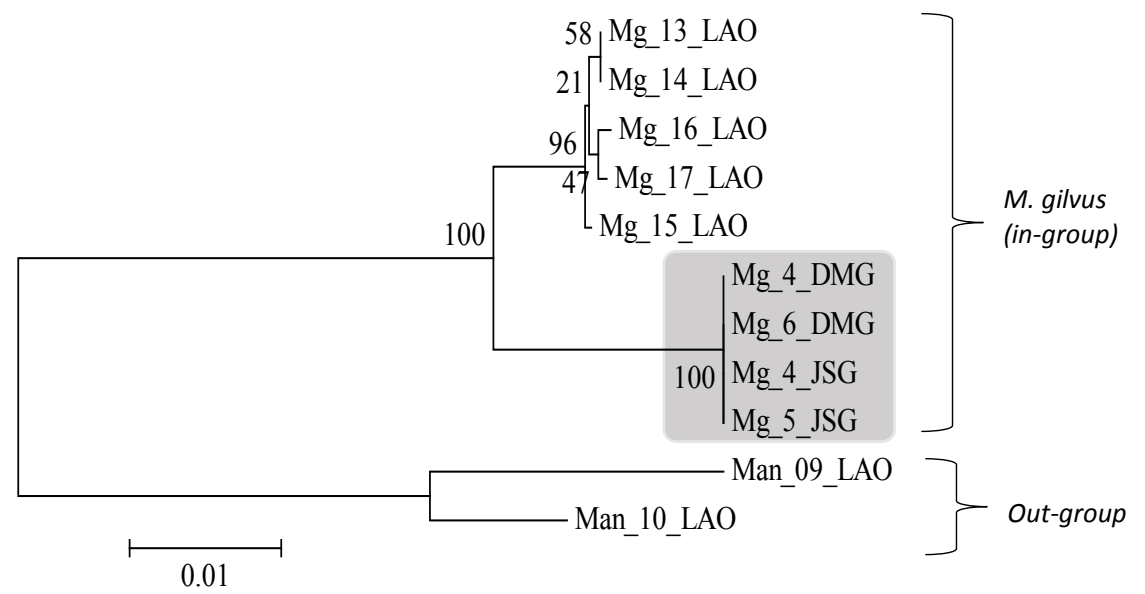

Gambar 2. Pohon filogenetika antara Macrotermes gilvus dan M. annandalei berdasarkan gen COI menggunakan metode Neighbor-Joining dengan bootstrap 1000x.

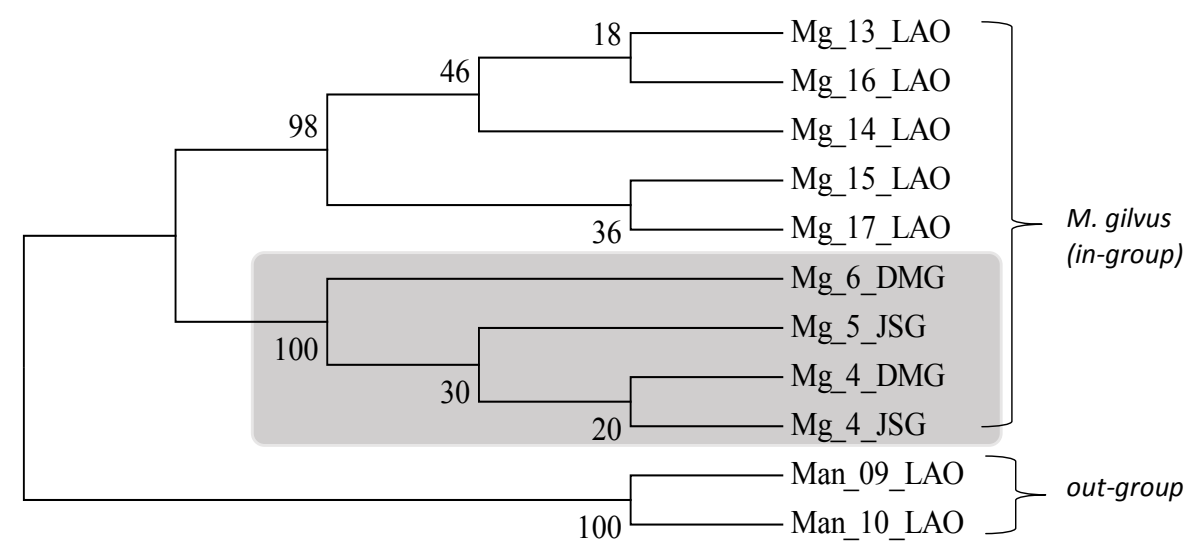

Gambar 3. Pohon filogenetika antara Macrotermes gilvus dan M. annandalei berdasarkan gen COI menggunakan metode Maximum-Parsimony dengan bootstrap 1000x.

Tabel 5. Hasil jarak genetik Macrotermes gilvus gen COI dengan sampel dari GenBank

\begin{tabular}{lrrrrrrrrrrr}
\hline & D4 & D6 & J4 & J5 & L13 & L14 & L15 & L16 & L17 & L9 & L10 \\
\hline$[\mathrm{D} 4]$ & & & & & & & & & & & \\
{$[\mathrm{D} 6]$} & 100 & & & & & & & & & \\
{$[\mathrm{~J} 4]$} & 100 & 100 & & & & & & & & \\
{$[\mathrm{~J} 5]$} & 100 & 100 & 100 & & & & & & & \\
{$[\mathrm{~L} 13]$} & 97,8 & 97,8 & 97,8 & 97,8 & & & & & & \\
{$[\mathrm{~L} 14]$} & 97,8 & 97,8 & 97,8 & 97,8 & 100 & & & & & \\
{$[\mathrm{~L} 15]$} & 97,9 & 97,9 & 97,9 & 97,9 & 99,8 & 99,8 & & & & \\
{$[\mathrm{~L} 16]$} & 97,6 & 97,6 & 97,6 & 97,6 & 99,8 & 99,8 & 99,7 & & & \\
{$[\mathrm{~L} 17]$} & 97,8 & 97,8 & 97,8 & 97,8 & 99,7 & 99,7 & 99,8 & 99,8 & & \\
{$[\mathrm{~L} 9]$} & 91,5 & 91,5 & 91,5 & 91,5 & 92,3 & 92,3 & 92,3 & 92,3 & 92,3 & & \\
{$[\mathrm{~L} 10]$} & 92,4 & 92,4 & 92,4 & 92,4 & 93 & 93 & 93 & 93 & 93 & 97,2 & \\
\hline
\end{tabular}

D4: Mg 4 DMG; D6: Mg 6 DMG; J4: Mg 4 JSG; J5: Mg 5 JSG; L13: Mg 13 LAO; L14: Mg 14 LAO; L15: Mg 15 LAO; L16: Mg 16 LAO; L17: Mg 17 LAO; L9: Man 9 LAO; dan L10: Man 10 LAO. 


\section{PEMBAHASAN}

Keempat sekuen rayap dari Bogor (CA Yanlappa-Jasinga dan Kampus IPB Dramaga) yang telah dianalisis homologinya memberikan hasil yang selaras dengan identifikasi rayap secara morfologi, yaitu merujuk pada spesies rayap M. gilvus. Analisis homologi dari sekuen basa nukleotida dari keempat rayap dari Bogor mempunyai basa nukleotida yang sama. Hal ini menunjukkan bahwa, rayap dari kedua lokasi masih mempunyai kekerabatan yang dekat. DNA mitokondria merupakan DNA yang diturunkan secara murni dari induk betina (maternal) (Simon et al. 2006) sehingga rayap yang dideteksi dengan teknik molekuler berdasarkan gen mtCOI menunjukkan bahwa rayap berasal dari tetua yang sama. Beberapa penelitian lain menunjukan bahwa gen COI mampu mengidentifikasi spesies dengan kemiripan morfologi yang tinggi (spesies kriptik). Sebagai contoh, hasil penelitian Bourguignon et al. (2013), berdasarkan morfologi berhasil mengidentifikasi 31 spesies rayap, akan tetapi setelah deteksi kembali menggunakan penanda genetik gen COI ternyata hanya ditemukan 3 spesies kriptik (Bourguignon et al. 2013).

Analisis kekerabatan menggunakan pendekatan perilaku menunjukkan bahwa rayap dari kedua lokasi diduga berasal dari tetua yang berbeda. Rayap pekerja yang terlihat saling agresif ini mengindikasikan bahwa rayap berasal dari induk yang berbeda karena isyarat yang dikeluarkan rayap pekerja dari masing-masing lokasi dikenali bukan sebagai anggota koloninya (nestmate), tetapi dikenali sebagai musuh atau rayap spesies yang lain. Pengujian dengan pendekatan perilaku menunjukkan bahwa rayap mampu mengenali isyarat yang dikeluarkan oleh rayap lain dengan sangat baik. Isyarat tersebut berupa kutikular hidrokarbon yang dapat dikenali oleh rayap lain, apabila rayap berasal dari tetua yang sama maka rayap akan memberikan respons dengan mengenalinya sebagai sesama anggota koloni. Sebaliknya, jika rayap berasal dari tetua yang berbeda maka individu rayap akan menunjukkan perilaku yang agresif (Shelton \& Grace 1996).

Hasil yang diperoleh antara pendekatan perilaku dan molekuler menunjukkan hasil yang belum selaras. Analisis menggunakan pendekatan perilaku menunjukkan hasil bahwa rayap $M$. gilvus berasal dari tetua yang berbeda. Akan tetapi, berdasarkan pendekatan molekuler menunjukkan hasil bahwa rayap mempunyai kedekatan yang tinggi berdasarkan gen COI. Hal ini menunjukkan bahwa aspek yang dikaji pada pendekatan perilaku dan deteksi molekuler perlu ditambahkan. Aspek pada pendekatan perilaku perlu dikaji kembali tentang struktur dari kutikular hidrokarbon. Kutikular hidrokarbon merupakan salah satu metode yang dapat digunakan untuk melihat kekerbatan rayap, sedangkan pada pendekatan molekuler perlu ditambahkan kajian tentang gengen pada mitokondria yang lain, seperti gen COII, COIII dan lainnya. Sehingga kajian yang dilakukan akan lebih menyeluruh dan diperoleh hasil yang selaras antar kedua pendekatan yang digunakan.

\section{KESIMPULAN}

Rayap M. gilvus berhasil diidentifikasi dari Kampus IPB Dramaga dan CA Yanlappa. Berdasarkan hasil analisis menggunakan pendekatan perilaku, rayap menunjukkan berasal dari tetua yang berbeda. Akan tetapi berdasarkan teknik molekuler, rayap dari masing-masing lokasi mempunyai sekuen yang sama (tidak ada variasi nukleotida) yang menunjukkan bahwa rayap masih berkerabat.

\section{DAFTAR PUSTAKA}

Bourguignon T, Šobotnik J, Hanus R, Krasulova J, Vrkoslav V, Cvacka J, Roisin Y. 2013. Delineating species boundaries using an iterative taxonomic approach: The case of soldierless termites (Isoptera, Termitidae, Apicotermitinae. Molecular Phylogenetics and Evolution 69:694703.

Busse HJ, Denner EBM, Lubitz W. 1996. Classification and identification of bacteria: current approaches to an old problem. Overview of methods used in bacterial systematics. Journal of Biotechnology 47:3-38. doi: http://dx.doi. org/10.1016/0168-1656(96)01379-X.

Cameron SL, Lo N, Bourguignon T, Svenson GJ, Evans TA. 2012. A mitochondrial genome phylogeny of termites (Blattodea: Termitoidae): Robust support for interfamilial relationships and molecular synapomorphies define major clades. 
Molecular Phylogenetics and Evolution 65:163173. doi: http://dx.doi.org/10.1016/j.ympev.2012. 05.034 .

Delphia CM, Copren KA, Haverty MI. 2003. Agonistic behavior between individual worker termites from three cuticular hydrocarbon phenotypes of Reticulitermes (Isoptera: Rhinotermitidae) from Northern California. Annals of the Entomological Society of America 96:585-593. doi: http://dx.doi.org/10.1603/00138746(2003)096[0585:ABBIWT]2.0.CO;2.

Ferbiyanto A, Rusmana I, Raffiudin R. 2015. Characterization and identification of cellulolytic bacteria from gut of worker Macrotermes gilvus. HAYATI Journal of Biosciences 22:197-200. doi: http://dx.doi.org/10.1016/j.hjb.2015.07.001.

Jinbo U, Kato T, Ito M. 2011. Current progress in DNA barcoding and future implication for entomology. Entomological Science 14:107-124. doi: http:// dx.doi.org/10.1111/j.1479-8298.2011.00449.x.

Legendre F, Whiting MF, Bordereau C, Cancello EM, Evans TA, Grandcolas P. 2008. The phylogeny of termites (Dictyoptera: Isoptera) based on mitochondrial and nuclear markers: Implications for the evolution of the worker and pseudergate castes, and foraging behaviors. Molecular Phylogenetics and Evolution 48:615-627. doi: http://dx.doi.org/10.1016/j.ympev.2008.04.017.

Mubin N. 2013. Keanekaragaman Spesies Rayap dan Bakteri Simbionnya: Studi Kasus di Kampus IPB Dramaga, Bogor. Skripsi. Bogor: Institut Pertanian Bogor.

Mubin N. 2014. Analisis Kekerabatan Rayap Tanah Macrotermes gilvus Hagen (Blattodea: Termitidae) dan Inventarisasi Bakteri Simbionnya di Bogor. Tesis. Bogor: Institut Pertanian Bogor.

Noirot CH, Noirot-Timothee C. 1969. The digestive system. Di dalam: Weesner FM, penerjemah; KrishnaK, WeesnerFM(Eds.), Biologyof Termites. hlm. 43-88. New York: Academic Press Inc.

Ohkuma M, Yuzawa H, Amornsak W, Sornnuwat Y, Takematsu Y, Yamada A, Vongkaluang C, Sarnthoy O, Kirtibutr N, Noparatnaraporn N, Kudo T, Inoue T. 2004. Molecular phylogeny of Asian termites (Isoptera) of the families Termitidae and Rhinotermitidae based on mitochondrial COII sequences. Molecular Phylogenetics and Evolution 31:701-710. doi: http://dx.doi.org/10.1016/j.ympev.2003.09.009.

Pearce MJ. 1997. Termites: Biology and Pest Management. New York: CABI.

Pribadi T, Raffiudin R, Harahap IS. 2011. Termites community as environmental bioindicators in highlands: a case study in eastern slopes of Mount
Slamet. Central Java. Biodiversitas 12:235-240. doi: http://dx.doi.org/10.13057/biodiv/d120409.

Primanda A, Ischak TM, Basukriadi A. 2003. Termite species richness on the campus of Universitas Indonesia. Depok. Makara Sains 71:9-14.

Roonwal ML, Chhotani OB. 1961. The Termite Macrotermes gilvus Malayanus (Haviliand) (Termitidae) in Burma. Proceedings of the National Academy of Sciences, India 27:308-316. Sambrook J, Fritsch EF, Maniatis T. 1989. Molecular Cloning: ALaboratorium ManualSecondEdition. New York: Cold Spring Harbor Laboratory Press. Shelton TG, Grace JK. 1996. Review of agonistic behavior in the Isoptera. Sociobiol 28:155-176.

Simon C, Buckley TR, Frati F, Stewart JB, Beckenbach AT. 2006. Incorporating molecular evolution into phylogenetic analysis. and a new compilation of conserved polymerase chain reaction primers for animal mitochondrial DNA. Annual Review of Ecology, Evolution, and Systematics 37:545-579. doi: http://dx.doi. org/10.1146/annurev.ecolsys.37.091305.110018.

Singla M, Sharma VL, Sobti RC, Sodhi M, Kumari M. 2013. Genetic relationship among Indian termites based on DNA sequence of mitochondrial $12 S$ ribosomal RNA gene. International Journal of Evolution 2:1-6. doi: http://dx.doi.org/10.4172/2324-8548.1000101.

Subekti N, Duryadi D, Nandika D, Surjokusumo S, Anwar S. 2007. Karakteristik habitat rayap tanah Macrotermes gilvus Hagen di Taman Nasional Ujung Kulon. Jurnal MIPA 30:227-232.

Subekti N. 2010. Kelimpahan, Sebaran, dan Arsitekstur Sarang serta Ukuran Populasi Rayap Tanah Macrotermes gilvus Hagen (Blattodea: Termitidae) di Cagar Alam Yanlappa, Jawa Barat. Disertasi. Bogor: Institut Pertanian Bogor.

Tamura K, Peterson D, Peterson N, Stecher G, Nei M. Kumar S. 2011. MEGA5: Molecular evolutionary genetics analysis using maximum likelihood, evolutionary distance, and maximum parsimony methods. Molecular Biology and Evolution 10:2731-2739. doi: http://dx.doi. org/10.1093/molbev/msr121.

Tarumingkeng RC. 1971. Biologi dan Pengendalian Rayap Perusak Kayu Indonesia. Bogor: LPPK.

Tho YP. 1992. Termites of Peninsular Malaysia. Kirton LG (Eds). Kuala Lumpur: Malayan Forest Records.

Wei S, Ni J, Yu M, Shi B. 2012. The complete mitochondrial genome of Macrotermes barneyi Light (Isoptera: Termitidae). Mitochondrial DNA 23:426-428. doi: http://dx.doi.org/10.3109 /19401736.2012.710215. 